\title{
Evaluation of Bone Mineral Density in Prepubertal Children with Familial Mediterranean Fever
}

\section{Ailevi Akdeniz Ateşi Tanısı ile İzlenen Prepubertal Çocuklarda Kemik Mineral Dansitesinin Değerlendirilmesi}

\author{
Emine Atağ ${ }^{1}$ (D), Sevliya Öcal ${ }^{2}$ (D), Müferet Ergüven ${ }^{3}$ (I)
}

${ }^{1}$ Medipol University, Pediatric Chest Diseases, Istanbul, Turkey
${ }^{2}$ Medeniyet University Göztepe Training and Research Hospital, Istanbul, Turkey
${ }^{3}$ Düzce University, Pediatric Rheumatology, Düzce, Turkey

ORCID ID: E.A. 0000-0003-3105-0409; S.Ö. 0000-0002-7175-3037; M.E. 0000-0002-3255-1208

Citation/Attf: Atag E, Ocal S, Erguven M. Evaluation of bone mineral density in prepubertal children with Familial Mediterranean Fever. Çocuk Dergisi Journal of Child 2021;21(2):89-93. https://doi.org/10.26650/jchild.2021.788750

ABSTRACT

Objective: Familial Mediterranean Fever (FMF) is a hereditary autosomal recessive chronic periodic inflammatory disease, characterized by recurrent fever polyserositis and skin manifestations. The aim of this study was to investigate the bone mineral density (BMD) in prepubertal children with FMF and to determine the relationship between bone density and demographic, laboratory characteristics of the disease.

Material and Method: Thirty two previously diagnosed, attack-free, prepubertal FMF patients who were receiving regular colchicine treatment were included in the study. Demographic and clinical data of patients, acute phase reactants, biochemical parameters of bone turnover, bone age, and L1-L4 vertebral mineral density were evaluated. The results of the patients were compared with values determined for healthy Turkish children.

Results: All of the patients had z-scores which were greater than -2. Acute phase values and bone metabolism markers were within normal limits. No correlation was found between the aBMD Z-score and demographic data, acute phase reactants and bone metabolism markers. There was a negative correlation between delay in diagnosis and aBMD Z- score. Conclusion: Although aBMD Z-scores were normal in children with FMF the aBMD Z score was found to be lower in children who had had a delay in treatment. Early initiated colchicine therapy is important for optimal bone health in these patients.

Keywords: Bone mineral density, children, familial mediterranean fever
Öz

Amaç: Ailevi Akdeniz Ateşi (AAA) otozomal ressesif kalıtılan tekrarlayan atateş, poliserözit ve cilt bulgularıla karakterize atakler ve remisyonla seyreden kronik periyodik inflamatuvar bir hastalıktır. Bu çalışma, AAA tanısıyla izlenen prepubertal çocuklarda kemik mineral yoğunluğunu (BMD) araştırmak ve kemik yoğunluğu ve hastalığın laboratuvar ve demografik özelikleri arasındaki ilişkiyi saptamak amacıyla yapılmıştır.

Gereç ve Yöntem: Bu çalışmaya AAA tanısıyla takipli ve kolşisin tedavisi alan prepubertal 32 hasta alındı. Hastaların demografik ve klinik verileri, remisyon döneminde akut faz reaktanları, kemik döngüsünün biyokimyasal parametreleri, kemik yaşı, L1-L4 vertebra BMD ölçümleri değerlendirildi. Hastaların sonuçları sağlıklı Türk çocukları için belirlenmiş olan değerlerle karşılaştırıldı.

Bulgular: Hastaların tamamında z skorları -2'den büyüktü, akut faz değerleri, kemik metabolizma belirteçleri normal sınırlar içinde bulundu. aBMD Z-skor ile demografik veriler, akut fazlar ve kemik metabolizma belirteçleri arasında korelasyon saptanmadı.Tanıda gecikme süresi ve BMD arasında negatif korelasyon saptandı.

Sonuç: AAA'li çocuklarda aBMD Z-skorları normal olmakla birlikte tanıya geç başlanılan çocuklarda BMD daha düşük bulundu. Erken başlanan kolşisin tedavisi bu hastalarda optimal kemik sağlığı için önemlidir.

Anahtar Kelimeler: Çocuk, inflamasyon, kemik mineral dansitesi

Corresponding Author/Sorumlu Yazar: Emine Atağ E-mail: emineatag@gmail.com

Submitted/Başvuru: 01.09.2020 • Revision Requested/Revizyon Talebi: 19.02.2021 • Last Revision Received/Son Revizyon: 22.02 .2021 •

Accepted/Kabul: 13.07.2021 


\section{INTRODUCTION}

Familial Mediterranean Fever (FMF) is a chronic inflammatory disease and has an autosomal recessive inheritance. It occurs mainly in people living around the Eastern Mediterranean Sea. Its reported incidence in the world is between $1 / 200$ and $1 / 1000$. Studies conducted in Turkey ave shown that incidence rates vary among regions, with Central Anatolian and Northern Anatolian regions being the highest $(0.88 \%)$. FMF is associated with recurrent fever, peritonitis, pleuritis, arthritis, pericarditis, and cutaneous symptoms as a result of mutations of the MEFV gene. The MEFV gene is found on chromosome 16. More than 70 mutations in the MEFV gene cause the disease, of which the majority are located in the $10^{\text {th }}$ and $2^{\text {nd }}$ exons $(1,2)$.

Recurrent attacks and remissions are the most important features of the clinical course of FMF. Many inflammatory cytokines including IL-1, IL-15, IL-11, IL-17, TNF, and IL-6 are essential in the pathogenesis, and the serum levels of these cytokines have been demonstrated to be associated with osteoclast activation and bone resorption. In patients with FMF, inflammatory cytokines reduce bone mineral density by adversely affecting the osteogenesis and increased resorption of bone $(3,4)$. In patients with loss of appetite due to the disease, malnutrition and immobility during attacks also contribute to the condition of bone mineral reduction (5). The most commonly used method to demonstrate bone mineral density is dual-energy x-ray absorptiometry (DXA)(6). This method determines bone mineral density (BMD) through the ratio of the bone mineral content to the measured bone area (7).

This study aimed to examine the bone mineral density using DXA in prepubertal children with FMF and to identify the relation between the laboratory and demographic characteristics of the disease and the bone density.

\section{MATERIAL AND METHOD}

Thirty two prepubertal patients who were being regularly followed-up after being diagnosed with FMF and whose records were regularly maintained were retrospectively evaluated. Tel-Hashomer criteria were used for the diagnosis of FMF. All the patients were receiving regular colchicine therapy. Data on the age, gender, age at the initiation of symptoms, age at diagnosis, clinical findings, time of initiation of colchicine, nutrition history, physical activities, familial history of FMF and consanguinity were recorded on the prepared FMF forms. The time from the initiation of symptoms to the initiation of colchicine therapy was defined as delay time of diagnosis and calculated. The disease severity was scored using the scoring system developed by Pras et al. Based on this scoring system, the patients were assessed according to age of onset, frequency of attacks, dose of colchicine required to control attacks, joint involvement, presence of erysipelas-like erythema and presence of amyloidosis. A score of 2 to 5 referred to a mild disease, a score of 6-10 to a moderate disease, and a score of higher than 10 to a severe disease (8). Height, weight and bone age measurements were taken, and body mass index (weight $/$ height $^{2}, \mathrm{~kg} / \mathrm{m}^{2}$ ) was calculated. The results of acute phase reactants were recorded, including WBC, erythrocyte sedimentation rate (ESR; Westergren method, normal $<20 \mathrm{~mm}$ / hour), C-reactive protein (CRP; nephelometric method, normal $<1.0 \mathrm{mg} / \mathrm{dl}$ ) calcium, phosphorus, alkaline phosphatase, parathormon, $25-\mathrm{OH}$ vitamin $\mathrm{D}$, spot urinary calcium-tocreatinine ratio, which are the biochemical parameters of bone turnover taken from all of the patients during the remission period (at least 2 weeks after exacerbation).

The BMD at the L1-L4 vertebrae, which had been measured using the DXA performed at the same center, were evaluated (Hologic QDR-4500A). The results were recorded as height adjusted areal bone mineral density (aBMD) Z-score. The results from the patients were compared to the standardized values for healthy Turkish children (9). Results with a z-score of $\leq-2.0$ SD were considered as low bone mineral density.

The study was directed following the principles of the Declaration of Helsinki and an ethical committee approval was obtained (committee approval number 2020/0258). Parents were informed and written consent was provided. Patients with chronic comorbidities or malnutrition in addition to the diagnosis of FMF were excluded from the study.

The SPSS 15 software was used for the statistical analyses. Normality test was performed to determine the distrubition of data. Since continuous variables had normal distribution, they were presented as mean \pm standard deviation (SD). Categorical variables were expressed as proportions. The Pearson correlation test was used for correlation between the normal distributed variables. A p-value $<0.05$ was taken to be statistically significant.

\section{RESULTS}

Of the 32 patients included to the study, the mean age was $6.9 \pm 1.4$ years and $12(37.5 \%)$ were girls. The mean age at the time of diagnosis was $4.7 \pm 1.7$ years. The time from the initiation of symptoms to the initiation of colchicine therapy (defined as delay time of diagnosis) was $1.6 \pm 0.5$ years (mean value). The mean severity score was $6.18 \pm 2.1$. The most common symptoms were abdominal pain observed in 31 patients $(96.8 \%)$, fever in 27 patients (84.3\%) and arthralgia in 13 patients (40\%). 13 (40\%) of our patients had familial history of consanguinity, and 11 (34.3\%) had familial history of FMF. It was observed that age-appropriate nourishment was provided and physical activities were within normal range in all the patients. Table 1 shows the demographic and clinical features of the children with FMF. Their acute phase reactants and bone metabolism markers were within normal ranges. The aBMD Z-scores of all patients were normal; the mean aBMD Z-score was $-0.83 \pm 0.66$ (Table 2). There was no correlation between aBMD Z-score and body mass index, age, and gender. The correlation between $\mathrm{Ca}, \mathrm{P}, \mathrm{ALP}, \mathrm{PTH}, 25-\mathrm{OH}$ vitamin D and spot urinary calcium-tocreatinine ratio (biochemical markers of bone metabolism) and aBMD Z-score was not significant. There was no correlation between the patients' severity score and aBMD Z-score. The correlation between delay time of diagnosis and aBMD Z-score was statistically significant (p:0.031, 0.017) (Table 3). 
Table 1: The demographic and clinical characteristics of the patients.

\begin{tabular}{lc}
\hline Gender (female/male) (n) & $12 / 20$ \\
Age (year, mean \pm SD) & $6.9 \pm 1.4$ \\
Age at the diagnosis (year, mean \pm SD) & $4.7 \pm 1.7$ \\
FMF severity score & $6.18 \pm 2.1$ \\
Delay time of diagnosis (year, mean \pm SD) & $1.6 \pm 0.5$ \\
Height (cm) & $114.93 \pm 8.17$ \\
Height z score & $-0.8 \pm 0.1$ \\
Weight (kg) & $20.5 \pm 2.46$ \\
Body mass index (kg/m²) & $15.19 \pm 1.25$ \\
Consanguinity n (\%) & $13(40 \%)$ \\
Family history for FMF n (\%) & $11(34.3 \%)$ \\
Abdominal pain n (\%) & $31(96.8 \%)$ \\
Fever n (\%) & $27(84.3 \%)$ \\
Arthritis/arthralgia n (\%) & $13(40.6 \%)$ \\
Myalgia n (\%) & $9(28.1 \%)$ \\
Chest pain n (\%) & $5(15.6 \%)$ \\
\hline
\end{tabular}

FMF: Familial Mediterranean Fever

Table 2: Laboratory findings of the patients.

\begin{tabular}{lc}
\hline WBC $(\mathrm{k} / \mathrm{ml})$ & $1709 \pm 39$ \\
ESR $(\mathrm{mm} / \mathrm{h})$ & $17.09 \pm 1.84$ \\
$\mathrm{CRP}(\mathrm{mg} / \mathrm{dl})$ & $0.13 \pm 0.06$ \\
$\mathrm{Ca}(\mathrm{mg} / \mathrm{dl})$ & $9.5 \pm 0.12$ \\
P $(\mathrm{mg} / \mathrm{dl})$ & $4.5 \pm 0.13$ \\
ALP $(\mathrm{IU} / \mathrm{L})$ & $256.12 \pm 15$ \\
PTH $(\mathrm{ng} / \mathrm{ml})$ & $49,53 \pm 5.8$ \\
25(OH)D $(\mathrm{nmol} / \mathrm{l})$ & $31.6 \pm 3.6$ \\
Spot urine Ca/kreatinin & $0.12 \pm 0.1$ \\
aBMD Z score & $-0.83 \pm 0.66$ \\
\hline
\end{tabular}

25-OH vit D: 25-hydroxyvitamin D, ALP: alkaline phosphatase, BMD: bone mineral density, Ca: calcium, CRP: C-reactive Protein, ESR: Erythrocyte sedimentation rate, P: phosphor, PTH: parathormon, WBC: White Blood Cell, Values expressed as mean $\pm \mathrm{SD}$.

\section{DISCUSSION}

FMF is a chronic inflammatory disease and its main features are periodic fever and serosal inflammation. As a result of mutations on the short arm of chromosome 16, attacks and increased inflammatory response during remission are observed $(1,2)$.

Many factors are responsible for bone mineral density in children, of which genetics, race, environmental factors, hormones and cytokines are the main factors. In FMF, loss of bone mass is observed due to subclinical inflammation that
Table 3: Correlations between demographic and laboratory characteristis and a(BMD) Z-score.

\begin{tabular}{|c|c|}
\hline & aBMD z score \\
\hline Age & $\begin{array}{l}r: 0.022 \\
p: 0.87\end{array}$ \\
\hline Gender & $\begin{array}{l}r: 0.054 \\
p: 0.236\end{array}$ \\
\hline BMI z-score & $\begin{array}{l}r: 0.100 \\
p: 0.463\end{array}$ \\
\hline $\mathrm{WBC}(\mathrm{k} / \mathrm{ml})$ & $\begin{array}{l}r:-0.309 \\
\text { p: } 0.085\end{array}$ \\
\hline $\operatorname{ESR}(\mathrm{mm} / \mathrm{h})$ & $\begin{array}{l}r:-0.233 \\
\text { p: } 0.199\end{array}$ \\
\hline $\mathrm{CRP}(\mathrm{mg} / \mathrm{dl})$ & $\begin{array}{l}r:-0.202 \\
\text { p: } 0.267\end{array}$ \\
\hline $\mathrm{Ca}(\mathrm{mg} / \mathrm{dl})$ & $\begin{array}{l}r:-0.161 \\
\text { p: } 0.237\end{array}$ \\
\hline$P(m g / d l)$ & $\begin{array}{l}\text { r: }-0.014 \\
\text { p: } 0.916\end{array}$ \\
\hline ALP (IU/L) & $\begin{array}{l}r:-0.003 \\
\text { p: } 0.982\end{array}$ \\
\hline PTH (ng/ml) & $\begin{array}{l}r:-0.123 \\
p: 0.504\end{array}$ \\
\hline $25(\mathrm{OH}) \mathrm{D}(\mathrm{nmol} / \mathrm{l})$ & $\begin{array}{l}r: 0.123 \\
\text { p: } 0.501\end{array}$ \\
\hline Spot urine $\mathrm{Ca} / \mathrm{kreatinin}$ & $\begin{array}{l}r:-0.342 \\
\text { p: } 0.055\end{array}$ \\
\hline FMF severity score & $\begin{array}{l}r:-0.130 \\
\text { p: } 0.478\end{array}$ \\
\hline Delay time of diagnosis & $\begin{array}{l}r:-0.418 \\
\text { p: } 0.017\end{array}$ \\
\hline
\end{tabular}

25-OH vit D: 25-hydroxyvitamin D, aBMD: areal bone mineral density, ALP: alkaline phosphatase, BMI: Body mass index, Ca: calcium, CRP: C-reactive Protein, ESR: Erythrocyte sedimentation rate, P: phosphor, PTH: parathormon, WBC: White Blood Cell.

also persists during the remission period. It is also due to loss of appetite, malnutrition, and inflammatory cytokines that increase bone resorption. IL-2 R, IL-1, IL-6, IL-8, TNF $\alpha$ are the main cytokines associated with bone resorption $(3,4)$.

In our study, prepubertal patients with FMF undergoing colchicine therapy were evaluated during the non-attack period. The aBMD Z-scores of our patients were compared to the normal values determined for healthy Turkish children. In all of our patients, the z-scores were within normal range and the mean values were similar to that of healthy children.

In our study, there was an inverse correlation between delayed initiation of colchicine therapy and aBMD Z-score values. Colchicine suppresses inflammation by binding to tubulin thereby inhibiting microtubular polymerization, neutrophil chemotaxis, IL-1 activation, and mast cell degranulation. There are no studies in the literature addressing the impact of colchicine on bone mineral density. Our study demonstrated that early initiation of therapy and reduction of 
the inflammatory burden during exacerbation and remission periods positively affect bone mineral density (10).

In a study conducted by Duzova et al., the BMD results of patients with FMF were compared to those of healthy children and it was observed that while the z-scores of all of the patients were greater than -2 (i.e within normal limits), the BMD z-scores of the patients were lower compared to healthy controls. In this study, the fact that the BMD z-scores were lower than the control group was more significant in patients with the homozygous mutation and was associated with the increased inflammatory burden of the patients (11).

The study conducted by Yildirim et al., which was one of the studies that investigated osteoporosis secondary to inflammation in FMF, compared patients diagnosed with FMF with a control group and found that the CRP and ESR values were increased and the $z$-scores were decreased in patients with FMF compared with healthy controls. The lower z-scores in the patients was attributed to persistent inflammation (12).

Two adult studies from Turkey found similar results. Suyani et al. investigated bone mineral density among FMF patients, and they showed that bone mineral content was lower in FMF compared to healthy adults (13). The second study investigating osteoporosis among 31 adult FMF patients revealed that adult FMF patients had decreased BMD Z scores. They also showed increased osteoprotegerin levels among patients as a compensatory response (14).

In our study, the patients' acute phase reactants were normal, and no correlation was found between the acute phase values and the aBMD Z-score values. The mean severity score of our patients was $6.18 \pm 2.1$, and $34 \%$ of them were in the mild disease group and $66 \%$ were in the moderate disease group. None of them was found to be severe. No correlation was found between the severity score and BMD. Additionally, no correlation was found between age at diagnosis and amyloidosis, which are severity score parameters, and BMD in the study directed by Duzova et al. In a study conducted by Kosan et al. which compared children with FMF to healthy children, the mean severity score of the patients was $6.74 \pm 1.26$, similar to our study, and no correlation could be demonstrated between the severity score and BMD score in this study either. In this study, the BMD values of the patients were slightly lower than the healthy controls, but this result was not significant (15).

According to recommendations in international guidelines, the growth and development process of patients, including the parameters of puberty, height z-score, and body mass index, should be taken into account when interpreting BMD results (16). In our study, weight, height, height standard deviation score, and body mass index values were within the age-appropriate normal ranges in all our patients. There was no correlation between the aBMD Z-scores and these parameters. In the maturation process of bone density, differences between genders start to appear during the puberty period. Due to this, no correlation was found between aBMD Zscore and gender in our study.
When evaluating bone mineral density, the densitometric examination is interpreted along with biochemical investigations showing bone formation and resorption. Osteogenesis and bone resorption normally continue in a balanced state. Markers of bone metabolism can be listed as general markers such as calcium, phosphorus, vitamin D and parathormone, bone-specific alkaline phosphatase, procollagen type 1 peptide, and osteocalcin indicating new bone tissue formation, and pyridinoline, deoxypyridinoline, serum carboxyterminal telopeptide levels relating to bone resorption. These markers have limited practical use in pediatrics, and are used in studies to evaluate early response to treatment rather than for diagnostic purposes. Moreover, the absence of reference values in a healthy population for these markers limits their routine use all around the world. The bone metabolism markers with common clinical use in children are ALP, $25-\mathrm{OH}$ vitamin $D$, calcium phosphorus, and the urinary calcium-to-creatinine ratio (17-19). In our study, the bone metabolism markers were normal, and no relationship was found between these markers and the aBMD Z-scores.

There are many studies in the literature evaluating the effects of vitamin D on bone density, and different results were obtained in these studies. In one study, the BMD and the factors affecting $B M D$ were examined in children with JIA. This study revealed that the BMD of the children with JIA was lower compared to the controls. Vitamin $D$ and phosphorus levels were lower in children with JIA, while the other parameters were similar to those of the control group. In this study, no correlation was found between the serum phosphorus, calcium, ALP, and vitamin D levels and the BMD values (20).

In a study by Duzova et al., the bone resorption parameters were similar in the patients and the control group, while the osteocalcin levels that indicate bone formation were lower in the patients, which was attributed to the fact that serum osteocalcin levels could not be determined appropriately because osteocalcin is labile and affected by storage conditions.

In the study conducted in patients with FMF by Yildirim et al., the patient and control groups were compared in terms of biochemical markers of bone metabolism and BMD. They showed that vitamin D levels were decreased in the patient group while the other bone metabolism markers and the BMD values were similar in both groups (21).

A study by Kosan et at. found that the bone metabolism markers of patients with FMF were similar to those of healthy children. The vitamin D levels of both groups were at the lower limit of the normal range, and the vitamin D levels were correlated with the BMD values in the patient group (15).

In conclusion, we observed that in children with FMF, a chronic inflammatory disease, the bone mineral density was similar to that of healthy children, but the BMD and z-score were correlated with the delay time of diagnosis and treatment. This study is important in that it demonstrates the positive effects of early diagnosis and treatment on bone health. It demonstrates 
that colchicine therapy will prevent inflammation, thereby positively affecting bone mineral health, along with its other effects.

Etik Komite Onayı: Çalışmamız Helsinki Bildirgesi ilkelerine göre oluşturuldu ve etik kurul onayı alındı (Komite onay numarası 2020/0258).

Bilgilendirilmiş Onam: Katılımcılardan bilgilendirilmiş onam alınmıştır.

Hakem Değerlendirmesi: Dış bağımsız.

Yazar Katkıları: Çalışma Konsepti/Tasarım- M.E., E.A.; Veri ToplamaE.A., S.Ö.; Veri Analizi/Yorumlama- E.A.; Yazı Taslağı- E.A., S.Ö.; İçeriğin Eleştirel İncelemesi- M.E.; Son Onay ve Sorumluluk- E.A., M.E., S.Ö.

Çıkar Çatışması: Yazarlar çıkar çatışması beyan etmemişlerdir.

Finansal Destek: Yazarlar finansal destek beyan etmemişlerdir.

Ethics Committee Approval: The study was directed following the principles of the Declaration of Helsinki and an ethical committee approval was obtained (committee approval number 2020/0258).

Informed Consent: Written consent was obtained from the participants.

Peer Review: Externally peer-reviewed.

Author Contributions: Conception/Design of Study- M.E., E.A.; Data Acquisition- E.A., S.Ö.; Data Analysis/Interpretation- E.A.; Drafting Manuscript- E.A., S.Ö.; Critical Revision of Manuscript- M.E.; Final Approval and Accountability- E.A., M.E., S.Ö.

Conflict of Interest: Authors declared no conflict of interest.

Financial Disclosure: Authors declared no financial support.

\section{REFERENCES}

1. Kucuk A, Albayrak Gezer I, Ucar R, Karahan AY. Familial mediterranean fever. Acta Medica 2014;57(3):97-104.

2. Cobankara V, Balkarli A. Ailesel Akdeniz Ateşi. Pam Med J 2011;4(2):86-98.

3. Duzova A, Bakkaloglu A, Besbas N, Topaloglu R, Ozen S, Ozaltin F, Bassoy $Y$, Yilmaz E. Role of serum amyloid $A(S A A)$ in monitoring subclinical inflammation and in colchicine dosage in familial Mediterranean fever. Clin Exp Rheumatol 2003;21:509-14.

4. Siverekli NB, Sahin O, Senel S, Hayta E, Kaptanoglu E, Elden H. Bone mineral density in familial Mediterranean fever. Rheumatol Int 2012;32:2453-7.

5. Burnham JM. Inflammatory diseases and bone health in children. Curr Opin Rheumatol 2012;24(5):548-53.
6. Williams KM. Update on Bone Health in Pediatric Chronic Disease. Endocrinol Metab Clin North Am 2016;45(2):433-41.

7. Specker BL, Schoenau E. Quantitative bone analysis in children: current methods and recommendations. J Pediatr 2005;146(6):72631.

8. Pras E, Livneh A, Balow JE Jr, Pras E, Kastner DL, Pras M, Langevitz P. Clinical differences between North African and Iraqi Jews with familial Mediterranean fever. Am J Med Genet 1998;75(2):216-9.

9. Goksen D, Darcan Ş, Coker M, Kose T. bone mineral density of healthy turkish children and adolescents. Journal of Clinical Densitometry 2006;9(1)84-90.

10. Slobodnick A, Shah B, Pillinger MH, Krasnokutsky S. Colchicine: old and new. Am J Med 2015;128(5):461-70.

11. Duzova A, Ozaltnn F, Ozon A, Besbas N, Topaloglu R, Ozen S, et al. Bone mineral density in children with familial Mediterranean fever. Clin Rheumatol 2004;23(3):230-4.

12. Yıldırım K, Karatay S, Çetinkaya R, Uzkeser H, Erdal A, Çapoğlu I, et al. Bone mineral density in patients with familial Mediterranean fever. Rheumatol Int 2010;30:305-8.

13. Suyani E, Ozturk MA, Deger SM, Demirag MD, Goker B, Haznedaroglu S. Decreased bone mineral density in adult familial Mediterranean fever patients: a pilot study. Clin Rheumatol 2008;27(9):1171-5.

14. Yuksel S, Samli H, Colbay M, Dundar U, Acarturk G, Demir S, et al. Increased serum osteoprotegerin levels associated with decreased bone mineral density in familial Mediterranean fever. Tohoku J Exp Med 2009;217(4):321-7.

15. Koşan C, Sepetçigil O, Çayır A, Kaya A, Özkan B. Evulation bone metabolism in children with familial Mediterranean fever. Turkish J Pediatr Dis 2012;6:139-45.

16. Bishop N, Arundel P, Clark E, Dimitri P, Farr J, Jones G, et al. International Society of Clinical Densitometry. Fracture prediction and the definition of osteoporosis in children and adolescents: the ISCD 2013 Pediatric Official Positions. J Clin Densitom 2014;17(2):275-80.

17. Sopher AB, Fennoy I, Oberfield SE. An update on childhood bone health: mineral accrual, assessment and treatment. Curr Opin Endocrinol Diabetes Obes 2015;22:35-40.

18. Zhang Y, Milojevic D. Protecting Bone Health in Pediatric Rheumatic Diseases: Pharmacological Considerations. Pediatr Drugs 2017;19(3):193-211.

19. Devogelaer JP, Boutsen Y, Gruson D, Manicourt D. Is there a place for bone turnover markers in the assessment of osteoporosis and its treatment? Rheum Dis Clin N Am 2011;37:365-86.

20. Dey S, Jahan A, Yadav TP, Bhagwani DK, Sachdev N. Measurement of bone mineral density by dual energy $\mathrm{X}$-ray absorptiometry in juvenile idiopathic arthritis. Indian J Pediatr 2014;81(2):126-32.

21. Aydın T, Taspınar O, Akbal Y, Peru C, Guler M, Uysal O, et al. Serum bone markers levels and bone mineral density in familial Mediterranean fever. J Phys Ther Sci 2014;26(9):1459-63. 